\title{
The status and management of the Mongolian gazelle Procapra gutturosa population
}

\author{
Badamjavin Lhagvasuren and E. J. Milner-Gulland
}

This article presents data on the ecology, exploitation and management of the Mongolian gazelle over the last few decades. The species has suffered a massive decline in its range area, coinciding with the construction of the Ulaanbaatar-Beijing railway in the 1950s. It is heavily hunted, both legally and illegally. Threats to the species are outlined and recommendations made about the conservation measures required to secure its future.

\section{Introduction}

Of the 14 species of ungulate inhabiting Mongolia, the Mongolian gazelle Procapra gutturosa has the largest population, both in terms of numbers and range area. It is a typical representative of the dry steppe and plain, i.e. open areas, although in certain years it can reach the southern edge of the mountain forest zone of Mongolia. The species resembles the goitred gazelle Gazella subgutturosa and saiga Saiga tatarica, also inhabitants of the arid plains of Central Asia, in some aspects of its biology, including the presence of horns, which are borne only by males, of medium size and lyrate in shape. When in peak condition (November-December) a male weighs on average $45 \mathrm{~kg}$ and a female $37 \mathrm{~kg}$.

Relatively recently the Mongolian gazelle was widely distributed in the regions of the Chuiskii Steppe (Kazakhstan), Daurian Steppe (Russian Federation) and the north-eastern area of China as far south as the Huanhe River. The Mongolian gazelle's range was about $780,000 \mathrm{sq} \mathrm{km}$ in 1950 , with a population of at least 1.5 million (Bannikov, 1954; Figure 1). Now, however, it has completely disappeared from the Russian Federation and only a small number remain in a limited area of China. Thus, it is listed as a disappearing species in the Red Data Book of the Russian Federation. The vast majority of Mongolian (c) $1997 \mathrm{FFI}$, Oryx, 31 (2), 127-134 gazelles is now to be found in Mongolia itself. The range is now about $190,000 \mathrm{sq} \mathrm{km}, 24$ per cent of its range 50 years ago (Figure 1). The species is found in large numbers in only four aimacs (provinces): Dornod, Khentii, Sukhbaatar and Dornogobi. In Umnugobi small herds are scattered over the Sevrey, Bayandalay and Bulgan sums (smaller administrative centres); in Uverkhangai small herds are found in the Guchin Us sum; in Dzavkhan in the Dorvoljin sum; in Bayankhongor in the Bogd sum and in Gobi-Altai in the Khokhmorit sum. This large reduction in range area is a cause for concern. Here we outline some of the reasons put forward for this reduction and present data on the ecology and management of the population. We then make recommendations for the actions required to ensure the future security of the species.

\section{Ecology of the Mongolian gazelle}

The plant communities of the Mongolian steppe have their maximum productivity at the end of July and beginning of August, producing $450-700 \mathrm{~kg}$ dry mass per ha. The new growth of vegetation starts at the end of May to the end of June, at the same time as the gazelles' mass parturition period. At this time the grass has its highest nutritional value, the protein content reaches its maximum level, 
and the biomass is $150-250 \mathrm{~kg} / \mathrm{ha}$ (Lushchekina et al., 1985). In June the Mongolian gazelle's diet consists of 21 species of plant: cereals (Stipa spp., Cleistogenes squarrosa) and onions (Allium spp.) are preferred. Leymus chinensis, Artemisia spp. and Caragana spp. are also favoured by the gazelle. About 80 per cent of the stomach contents in August are onions (Lushchekina, 1990). Experiments on food digestion and food value have shown that the mean amount of food consumed by young gazelles in July-August is $570 \pm 19.5 \mathrm{~g}$ or 64.5 $\pm 0.96 \mathrm{~g} / \mathrm{kg}$ of live weight. The digestibility of steppe grasses for the gazelle is $84.2 \pm 1.1$ per cent (Petrischev et al., 1990).

The Mongolian gazelle is a strongly seasonal breeder, although breeding dates vary quite widely from year to year, depending principally on the climate in the previous year. The rutting season usually starts on 15 November and continues until the first week of February. The gazelle is polygynous. One male can mate with 6-25 females, but the average harem size is 13 females to one male. A male is sexually mature at the age of 2.5 years, and a female at 1.5 years. Females gather in huge herds during the birth period, when 40,000 animals can remain for 2 weeks in an area of $35 \mathrm{sq} \mathrm{km}$. Females usually give birth from mid-June to mid-July but the variance is such that, in 1981 births were over by 2 June, in 1982 births occurred from 25 June to $12 \mathrm{July}$, and in 1983 they started on 2 July. However, about 90 per cent of females giving birth do so over a period of only 4-7 days (Lushchekina, 1990), and Tsagaan (1980) observed that $60-70$ per cent of the females gave birth at the beginning of July. The gestation period is $180-200$ days. In good years $60-85$ per cent of females give birth, usually to one, and seldom to two, lambs. However, Ganzorig and Dash (1982) recorded only 40 per cent of females giving birth. The percentage of twins is 2.5-8.2 per cent (Ganzorig and Dash, 1982; Lhagvasuren, 1985; Lushchekina, 1990). Lactation finishes at the end of November.

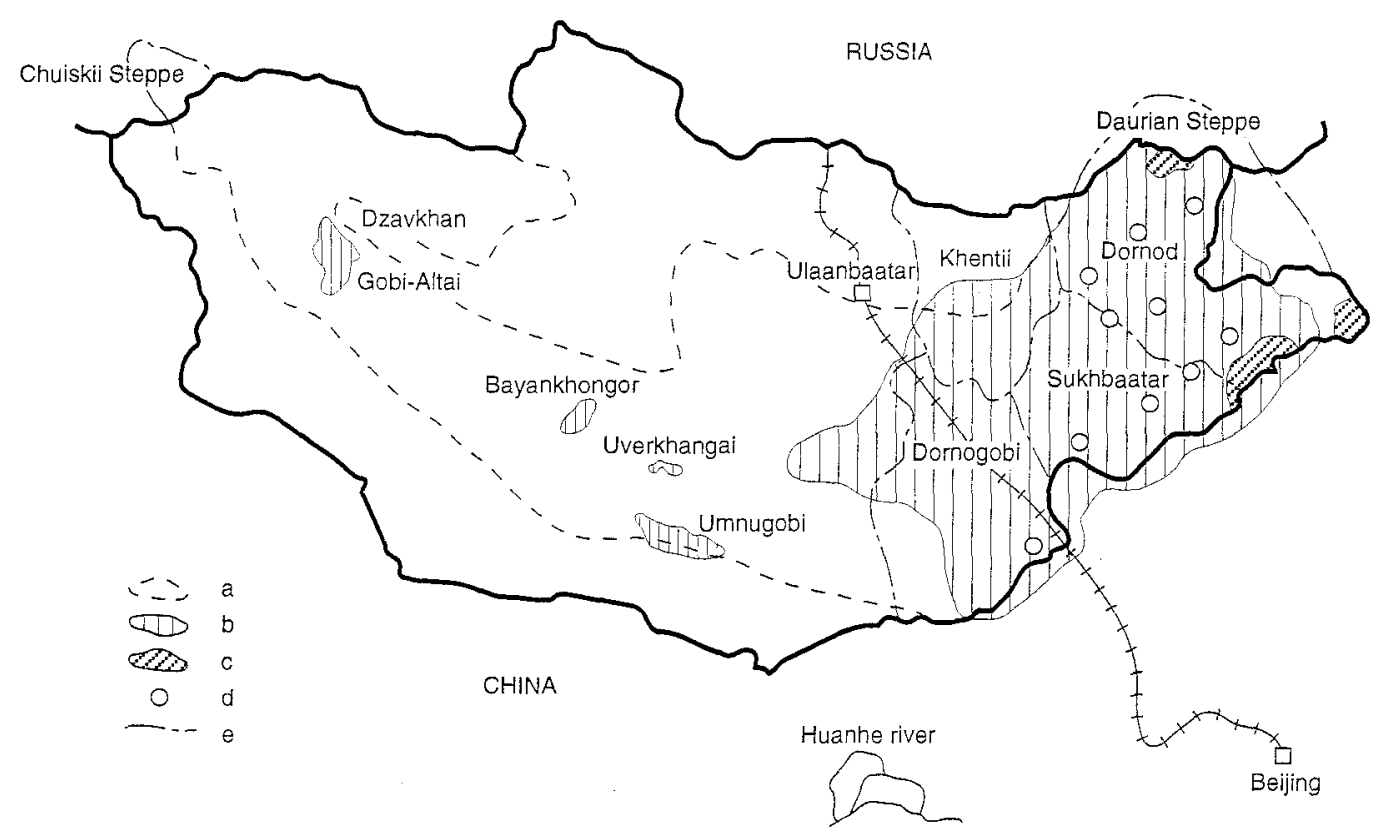

Figure 1. Map of Mongolia, showing the range of the Mongolian gazelle and places mentioned in the text; a, the boundary of the 1940s range area; $b$, the present-day range area; $c$, the Eastern Steppe National Park; $d$, major gazelle birth areas; e, the probable boundary of the 1940 s range area outside Mongolia. 
The annual rate of population increase has been observed to be 19-29 per cent in recent years, with factors such as climate, disease and hunting affecting the figure from year to year (Lhagvasuren, 1985, 1990; Lushchekina, 1990).

A distinguishing feature of the Mongolian gazelle is its permanent nomadism, as is also observed in saiga. Only in the birth and rutting seasons do they stay in particular places for a short time. In the winter gazelles prefer to stay in areas with patchy snow or near water sources. A proportion of the population migrates across the Mongolia-China border every year, moving to Mongolia in AugustOctober and back to China in March-April (Tsagaan, 1980). The maximum herd size that has been observed is about 80,000 animals and is seen during the spring (May) and autumn (September-October) migrations. During migration gazelles can easily cover $40-80 \mathrm{~km}$ per day. Unfortunately, the direction, frequency and other important features of the Mongolian gazelle's migration pattern are still unknown.

The main predators of the Mongolian gazelle are wolves, dogs and steppe eagles. Manul Felis manul and red fox Vulpes vulpes can catch lambs just after birth. In the winter the wolf is the major predator, especially after rutting when males have lost energy and are unable to run for long. The distribution of the gazelle is greatly influenced by the activity of the vole Lasiopodomys brandtii. For example, in the last 10 years a large increase in the $L$. brandtii population has destroyed a huge area of pasture in Sukhbaatar and Dornod provinces and the gazelles have disappeared from these areas and moved north.

Periodical epidemics, state hunting and poaching have also had a big influence on the decline in the number of gazelles. For example, in 1974 in eastern Mongolia about 140,000 animals were killed by an unknown disease. The same type of epizootic, but with fewer dead animals, has occurred regularly since then (Table 1). Partial investigation has shown that the gazelles died from Pasteurella (Dash and Sokolov, 1986) and that they are also carriers of Rickettsia, influenza, anthrax and foot-and-mouth disease (Lhagvasuren
Table 1. The number of Mongolian gazelles estimated to have died from disease, 1974-1994

\begin{tabular}{lc}
\hline Year & Numbers \\
\hline 1974 & 140,000 \\
1980 & 15,000 \\
1983 & 40,000 \\
1984 & 2,000 \\
1985 & 20,000 \\
1986 & 15,000 \\
1989 & 5,000 \\
1991 & 3,000 \\
1993 & $15,000-20,000$ \\
1994 & 3,000
\end{tabular}

Data for 1974 from Dash and Sokolov (1986), the rest are from $B$. Lhagvasuren.

and Luvsantseren, 1996). Places where high losses of Mongolian gazelles from Pasteurella infections have been recorded have been found to coincide with areas with abnormally high molybdenum levels in onions, which are the gazelles' favourite food in summer and autumn. These data suggest the possibility that abnormalities in environmental chemistry can be a cause of Pasteurella infections (Rothschild et al., 1988). Influenza is a big problem among Mongolian wildlife. Although no clear epidemic has been reported in Mongolian gazelles, serological investigations carried out in 1979-82 found antibodies to 14 different strains of the influenza virus in the Mongolian gazelle. One of these strains was known to have been the cause of a recent epidemic (Lushchekina et al., 1988).

Climatic conditions are an important factor in gazelle population dynamics. Severe winters (called dzhuts) kill thousands of animals at irregular intervals, with the average interval being 7 years since reliable records started in 1932. The years with recorded dzhuts this century are $1936 / 7,1944 / 5,1947 / 8,1957 / 8$, $1967 / 8,1970 / 1,1975 / 6,1980 / 1,1985 / 6$. The influence of harsh winters on gazelle population dynamics is likely to interact with the level of hunting mortality, so that as hunting mortality rates increase, the influence of dzhuts on the population will be proportionally greater (Milner-Gulland, 1994). 


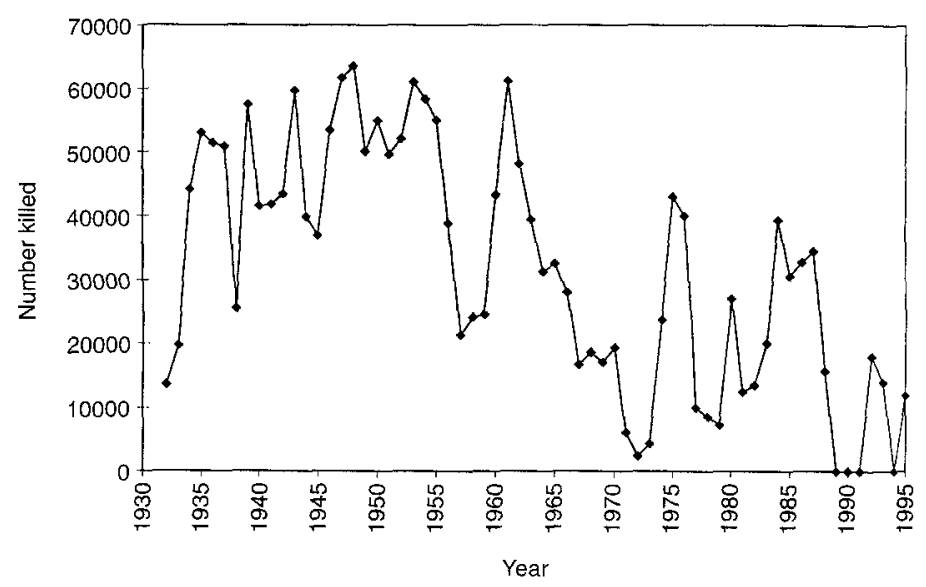

Figure 2. State hunting data for the number of Mongolian gazelles killed in Dornod province from 1932 to 1995 . In years when hunting took place, but data are not available (1974, 1978, 1989), the numbers killed are assumed to be the average of the number killed in the adjacent years. The data for 1951-72 are only available in tonnes and have been converted to numbers killed using the mean weight calculated from 1980 to 1983 , when data on both tonnages and numbers killed are available. Anecdotal data (not included here) suggest an extra state kill of around 100,000 animals per year in 1941-45 (Bannikov, 1954).

\section{Exploitation of the Mongolian gazelle}

From time immemorial the Mongolian gazelle has been hunted by Mongolian nomads, who used its tasty meat and durable skin. Hunting still continues today, and has been state-controlled since 1932 (Figure 2). The products of hunting are high-quality meat, tongue, skin, horn and subproducts (liver, heart, lungs, kidneys and fat). Formerly, most of the gazelle meat was shipped to eastern Europe, but in 1993 it all remained in Mongolia. The state hunting organizations are profitable enterprises; in 1988, 293 tonnes of meat was harvested, giving revenues of \$US498,100 (\$1.7 per $\mathrm{kg}$ ). The hide is a raw material for making good-quality box-calf and chamois. The Mongolian Institute of Oriental Medicine has made a preparation called 'Procaprin' from the bony core of gazelle horns and reindeer Rangifer tarandus velvet, which has been shown to calm muscular spasms of the gut and narrowing of the peripheral vessels in laboratory animals. It also seems to be effective on humans and has been granted a licence (Khaidav et al., 1986). Recently the price of horns has increased with exports to China. Chinese people pay $\$$ US1 per $\mathrm{kg}$ of horn (about 2.5 pairs), but this is still a relatively low price compared with the meat value of a carcass. Thus the Mongolian gazelle has not suffered the large-scale export-driven poaching for horn suffered by the saiga antelope (Chan et al., 1995).

The number of Mongolian gazelles hunted each year has varied considerably since 1932 (Figure 2). The largest number killed by the state was during the World War II, when the meat was used to provision soldiers; Bannikov (1954) stated that between 1941 and 1945 100,000 gazelles were killed each year. This heavy harvest was followed by several years with severe winters, but state hunting continued none the less, probably contributing to the rapid decline of the population in the $1950 \mathrm{~s}$ 60s (Sokolov et al., 1982). From the 1970s onwards, the Government of Mongolia has occasionally stopped state hunting for a few years in response to concerns about the status of the population.

Hunting occurs from 15-20 November to 10 December, stopping just before the peak of the rutting season (mid-December to midJanuary). Male-biased hunting before and during the rut could have serious consequences for the fecundity of the population, as has been suggested for other ungulate species (Ginsberg and Milner-Gulland, 1994). According to unpublished data from the hunting organization, harvests usually consist of about 60 per cent females and 40 per cent males, although officials from the hunting 
Table 2. Number of Mongolian gazelles killed by hunting, with the proportion in each sex and age class during the autumn and winter, from state hunting data

\begin{tabular}{|c|c|c|c|c|c|}
\hline \multirow[b]{2}{*}{ Location } & \multirow[b]{2}{*}{ Year } & \multicolumn{3}{|c|}{ Proportion in each class } & \multirow[b]{2}{*}{ Total } \\
\hline & & Adult males & Adult females & Juveniles & \\
\hline Gurvan Ders & 1979 & 0.39 & 0.42 & 0.20 & 7,210 \\
\hline $\begin{array}{l}\text { Sangiin Dalai, Byaruut, } \\
\text { Gurvan Ders }\end{array}$ & & & & & \\
\hline Sangiin Dalai, Dov Huv, & 1983 & 0.31 & 0.30 & 0.13 & 20,000 \\
\hline $\begin{array}{l}\text { Ereen, Byaruut } \\
\text { Ereen, Buyan-Under, }\end{array}$ & 1984 & 0.24 & 0.58 & 0.18 & 39,329 \\
\hline $\begin{array}{l}\text { Tamsagbulag } \\
\text { Sangiin Dalai, Buyan Undriin }\end{array}$ & 1985 & 0.17 & 0.57 & 0.26 & 30,000 \\
\hline Gobi, Ereen & 1986 & 0.18 & 0.5 & 0.32 & 10,682 \\
\hline Doloodoin Gobi, Ulaan Gobi & 1987 & 0.29 & 0.38 & 0.33 & 4,500 \\
\hline $\begin{array}{l}\text { Ereen, Sangiin Dalai } \\
\text { Buyan Undriin Gobi, }\end{array}$ & 1988 & 0.34 & 0.62 & 0.04 & 15,770 \\
\hline Khongor & 1995 & 0.38 & 0.62 & 0 & 5,186 \\
\hline
\end{tabular}

All hunting locations are in Dornod province except Byaruut (Sukhbaatar), Doloodoin Gobi and Ulaan Gobi (Dornogobi).

organization state that they actively attempt to shoot males. Although data are available on the sex ratio of the hunted population (Table 2 ), this information does not allow us to infer trends in the sex ratio of the population as a whole. However, in the 1980 s the observed herd sex ratios were 7-10 females per male in autumn, 13:1 in winter and 20:1 in summer (Lhagvasuren, 1985), while Bannikov (1954) observed a herd sex ratio in the 1940 s of 1.9 females to 1 male. These data are suggestive, but more are needed.

Poaching has continued throughout the period of state hunting control. Poaching is a serious threat to the Mongolian gazelle because it is carried out on a large scale. It is also selective for males, reinforcing the selectivity of state hunting. Approximate calculations suggest that each year poachers hunt 80,000 animals in total, at least $80-85$ per cent of which are males. This figure includes killing by Chinese border guards, who actively hunt Mongolian gazelles as they migrate across the border each year. The Mongolian border guards in the Mongolian Eastern Steppe National Park stated that the Chinese army hunts large numbers of gazelles continually at night from October to February using jeeps, trucks, spotlights and automatic weapons. It is reported that they have even pursued gazelles as far as $2 \mathrm{~km}$ into Mongolia. Mongolian border guards and families living near the border also hunt gazelles as they migrate.

Poaching is prohibited by law and offenders are prosecuted if caught. In 1995 a new hunting law was introduced, setting a fine of 15-20,000 tugrics (\$US30-40) for each gazelle killed by a poacher. The usual method of law enforcement is for the Ministry of Nature and the Environment, together with other organizations, to carry out poaching control in the autumn, before rutting and state hunting take place. This operation does catch poachers but it is financially constrained and, given the huge areas involved, it is impossible to catch enough poachers for effective deterrence.

Historical data suggest that in the 18 th and 19 th centuries, Mongolian gazelles were common both in the west of the country and in the east, but that by 1975-79, surveys found very few gazelles in the west (Sokolov et al., 1982). Now only a few local populations of the Mongolian gazelle remain in certain parts of western and southern Mongolia. In the early 1990 s about 25,000 animals were counted to the west of the Ulaanbaatar-Beijing railway (Figure 1). The reasons for the decline in the western populations of the Mongolian gazelle 
are unclear - proximate causes given for particular populations include bad weather and overhunting, although general development of the western parts of the country, including settlements, water holes and roads are also implicated (Sokolov et al., 1982). One major factor that may have been involved in the population decline is the construction of the Ulaanbaatar-Beijing railway at the end of the 1950s, which closed the gazelles' migration routes from eastern to western Mongolia. This cutting off of migration routes from east to west may have been a critical factor or coincidental - the data are unclear. Over the last 5 years gazelles have attempted to cross the railway and in certain places about 500 individuals crossed to the west.

Lushchekina et al. (1983) stated that the dry steppe of the eastern part of Mongolia is the optimal habitat for Mongolian gazelles, based on relative densities found there and in other habitat types. However, this pattern of density also shows a clear inverse relationship between livestock numbers and presence of Mongolian gazelles, suggesting that, rather than necessarily being the ecologically preferred habitat, it may simply be the least disturbed. A survey carried out in the autumn of 1994 by Nature Conservation International, the UN Mongolian Biodiversity Project and Mongolian zoologists counted 26 per cent of the gazelle population in dry steppe areas, 30 per cent in steppe, 23 per cent in hilly steppe areas and only 14 per cent in semi-desert areas, confirming the gazelle as a species of the steppe rather than desert, at least at that time of the year.

\section{Current management measures}

The first attempt to reintroduce Mongolian gazelle from the east of the country to the west was made in 1978, when several adult gazelles were captured and carried by small aircraft to an area in Uverkhangai province. There are no data on the success of this reintroduction. The second reintroduction, which was successful, was carried out in 1988-90. Six hundred newborn gazelles were taken by aeroplane from an area in Dornod province to the Khomin Tal steppe in Dzavkhan province, where the local population had decreased to about 600 animals. A survey carried out last year showed that the population has already risen to more than 3500 gazelles.

At present, the size of the gazelle population in Mongolia is uncertain. Bannikov (1954) estimated that in the 1940s Mongolia contained around 1,000,000 gazelles. Tsagaan (1980) estimated 250,000-270,000 gazelles in 1978. Lushchekina (1990) estimated the population at 180,000-200,000 gazelles in 1975-76, 250,000 in 1979 and 300,000-400,000 in 1982. In an air survey in 1989 Mongolian zoologists estimated a population of about 400,000 gazelles. However, the last air survey, carried out by Nature Conservation International, the UN Mongolian Biodiversity Project and Mongolian zoologists in 1994, estimated a population of about $2,000,000$ gazelles. These data need to be verified by a second air survey at the same time of year.

The recently established Ministry of Nature and Environment created the Eastern Steppe National Park 2 years ago to protect the Mongolian gazelles on its territory. This is the first national park in the Mongolian gazelle's range area but, unfortunately, it is not in an area of major importance for the gazelle (Figure 1).

At present, biological and ecological research on the Mongolian gazelle is carried out by the Institute of General and Experimental Biology of the Mongolian Academy of Sciences. From 1975 to 1985 , gazelle ecology was studied by the Mongolian gazelle team of the Joint Biological Expedition of the Mongolian and Soviet Union Academies of Science. Although a lot of research has been carried out on the gazelle, there are many topics, such as its seasonal migration, population genetic structure and pathogens, still waiting for further research. In particular, using advanced radiotelemetry to observe the range area of the gazelle and migration patterns would help us to understand the Mongolian gazelle's life history, its role in the ecosystem, and the impact of human activities and pasture usage on it. We still do not know much 
about the the genetic structure of the Mongolian gazelle and whether there are differences between gazelle populations in the east and west. One study suggests that some genetic differences may exist between different populations in the east (Lushchekina et al., 1983), but the limited analysis did not produce any firm conclusions. The study of the genetic differences between populations is important for planning conservation strategies, such as the reintroduction of gazelles into the west using animals from the east.

In 1994 the Society for the Conservation of the Mongolian gazelle was formed, with Badamjavin Lhagvasuren as the Executive Director. The Society was the initiative of a group of scientists and gazelle experts, and its main aim is the conservation of this vulnerable species. The Society also aims to improve the ecological awareness of the Mongolian people and to promote research into the biology of the Mongolian gazelle. The Society was founded with the financial and moral support of Nature Conservation International, Germany, and the United Nations Mongolian Biodiversity Project.

\section{Recommendations}

Some of the actions needed to secure the future of the Mongolian gazelle as a numerous and economically valuable species for the people of Mongolia are listed below.

- Strengthening antipoaching activities.

- Information and education about the gazelle for local people.

- Protection of the birth and rutting areas.

- Signing a joint agreement between Mongolia, China and Russia on conservation activities for the Mongolian gazelle in areas where the gazelle's range is adjacent to or crosses national borders. At present, research is very difficult in areas where gazelles cross national borders.

- Obligatory air surveys at least twice an year (before birth and hunting).

- Investigation of epidemics and their causes.

- Detailed investigation of migration routes using satellite telemetry.
- Investigation of the genetic structure of gazelle populations in the east and west, and any differences between them.

- Creation of a Management Programme for the major populations of the Mongolian gazelle.

The decline of the Mongolian gazelle population, whose main stronghold is in Mongolia, should be of concern not only to Mongolians but to the world in general. The conservation of the Mongolian gazelle, leading, it is hoped, to a recovery in population size and range area, is becoming a crucial task for Mongolia.

\section{Acknowledgements}

This paper was prepared while Badamjavin Lhagvasuren held a Royal Society funded Research Fellowship at the Ecosystems Analysis and Management Group, Department of Biological Sciences, University of Warwick, UK. We thank David Mallon for his help.

\section{References}

Bannikov, A.G. 1954. The Mammals of the Mongolian People's Republic. Publishing House of the Academy of Sciences of USSR, Moscow. Issue 53. (In Russian.)

Chan, S., Maksimuk, A.V., Zhirnov, L.V. and Nash, S.V. 1995. From Steppe to Store: The Trade in Saiga Antelope Horn. TRAFFIC International, Cambridge, UK.

Dash, Ya. and Sokolov, M.N. 1986. The reduction of stocks of Mongolian gazelles in Mongolia, its possible causes and recommendations for their conservation. In Natural Conditions and Biological Resources of the Mongolian People's Republic. Proceedings of International Conference, Moscow, USSR. (In Russian.)

Ganzorig, S. and Dash, Ya. 1982. The Organization of Mongolian Gazelle Herds in the Summer. Works of the Institute of General \& Experimental Biology of the Mongolian Academy of Sciences, N17. Ulaanbaatar, Mongolia. (In Russian.)

Ginsberg, J.R. and Milner-Gulland, E.J. 1994. Sex-biassed harvesting and population dynamics: implications for conservation and sustainable use. Conservation Biology, 8, 157-166.

Khaidav, Ts., Varlamova, T.S., Tsendem, Ts., Purevsuren, G., Tchanginjav, L., Dondov, P., Dash, Ya. and Neronov, V.M. 1986. A preparation from the horns of the Mongolian gazelle. In Natural Conditions and Biological Resources of the 
Mongolian People's Republic. Proceedings of International Conference. Moscow, USSR. (In Russian.)

Lhagvasuren, B. 1985. Population Ecology of the Mongolian Gazelle. Report of Field Work, 1981-1985. Mongolian Academy of Sciences, Ulaanbaatar. (In Mongolian.)

Lhagvasuren, B. 1990. Population Ecology of the Mongolian Gazelle. Report of Field Work, 1986-1990. Mongolian Academy of Sciences, Ulaanbaatar. (In Mongolian.)

Lhagvasuren, B. and Luvsantseren, R. 1996. Mongolian Gazelle Disease Investigation Trip Report. Report to the Mongolian Biodiversity Project, Ulaanbaatar. (In Mongolian.)

Lushchekina, A.A. 1990. The eco-geographical basis for the conservation and rational use of the Mongolian gazelle in Mongolia. Abstract of PhD thesis, Russian Academy of Sciences, Moscow, USSR. (In Russian.)

Lushchekina, A.A., Neronov, V.M. and Shurkhal, A.V. 1983. The territorial structure, intraspecific variation and questions of the rational use of the stock of Mongolian gazelles. In Applied Aspects in the Programme on Man and the Biosphere. Moscow, USSR. (In Russian.)

Lushchekina, A.A., Neronov, V.M. and Yamnikova, S.S. 1988. On the epizootic of flu among Mongolian gazelles. In The Natural Conditions, Vegetation Cover and Animal World of Mongolia. Puschino, Moscow, USSR. (In Russian.)

Lushchekina, A.A., Neronov, V.M., Ogureeva, G. and Sokolova, A. 1985. Distribution, ecology and conservation of the Mongolian gazelle Procapra gutturosa (Pallas 1777). Arch. Naturschutz und Landschaftsforsch, 25 (1), 57-69. (In German.)
Milner-Gulland, E.J. 1994. A population model for the management of the saiga antelope. Journal of Applied Ecology, 31, 25-39.

Petrischev, B.I., Magomedov, R.D. and Lhagvasuren, B. 1990. Experimental investigation of the Mongolian gazelle. In Methodological Questions in the Assessment of the Status of the Natural Environment in Mongolia. Proceedings of International Symposium. Puschino, Moscow, USSR. (In Russian.)

Rothschild, E.V., Yevdokimova, A.K. and Amgalan, Zh. 1988. Abnormalities of mineral composition in plants as a factor in the loss of the Mongolian gazelle in Mongolia. Bulyetin Moskovskovo O-va ispitatelei prirodi. Otdel Biologiyi. 93 (2), 35-42. (In Russian.)

Sokolov, V.E., Dash, Ya., Luschekina, A.A. and Neronov, V.M. 1982. Current distribution and numbers of Mongolian gazelles in Mongolia. In Zoological Research in Mongolia. Nauka, Moscow. (In Russian.)

Tsagaan, S. 1980. The Distribution, Migration, Herd Structure and Number of the Mongolian Gazelle. Works of the Institute of General \& Experimental Biology of the Mongolian Academy of Sciences, Ulaanbaatar. (In Mongolian.)

Badamjavin Lhagvasuren, Institute of General \& Experimental Biology, Mongolian Academy of Sciences, Ulaanbaatar 51, Mongolia.

E. J. Milner-Gulland, Ecosystems Analysis and Management Group, Department of Biological Sciences, University of Warwick, Coventry CV4 7AL, UK. 